Journal of Teacher Education for Sustainability, vol. 15, no. 1, pp. 15-47, 2013

\title{
POSITIVE YOUTH ACTION TOWARDS CLIMATE CHANGE
}

\author{
Karen Buttigieg and Paul Pace \\ The University of Malta, Malta
}

\begin{abstract}
This study focuses on the experiences of young people who are leaders of change in the environmental field. This study views environmental activism as a personal commitment towards pro-environmental behaviour. The motivations and challenges of such work are viewed as important to learn more not only about volunteering in environmental organisations, but also about pro-environmental behaviour. The main research problem was to explore these individuals' present and past life experiences, in the light of their activism, towards the issue of climate change. Narrative inquiry was chosen as a methodology for this research as it gives importance to experience and facilitates the study of an issue in all of its wholeness and complexity. The research involved in-depth interviews with three participants as well as living alongside the participants in an effort to build a relationship with them and to experience being an environmental activist. The participants were members of a local environmental organisation - Friends of the Earth (Malta). The outcomes of this study provide an opportunity for reflection on the factors that affect pro-environmental attitudes and behaviour and their implications on environmental education. This reflection will enable informed efforts to engage more young people in environmental activism. From the narratives produced, it is clear that there is no single factor that is optimal for promoting pro-environmental behaviour and environmental activism. These are, in fact, determined by a combination of interrelated factors.
\end{abstract}

Key words: narrative inquiry, youth, education for sustainable development, activism, climate change, friends of the earth

\section{Introduction}

Environmental problems are ultimately a result of human behaviour and can thus be mitigated and reversed also through human behaviour - not just through scientific and technological solutions (Oskamp, 2000). This means that Education for Sustainable Development (ESD) has a key role in the resolution to such problems (United Nations Educational, Scientific and Cultural Organisation [UNESCO], 2005). The 2007 Highlevel Planning meeting acknowledged climate change as a world concern that needs to be part of the awareness, learning and education for a sustainable future (UNESCO, 2007).

The world's 1.2 billion young people aged 15-24 constitute 18 per cent of the global population (United Nations [UN], 2007). Agenda 21 (United Nations Conference 
on Environment and Development [UNCED], 1992) identified youths as key stakeholders that have a unique contribution to make towards sustainable development and dedicated Chapter 25 to the importance of children's and young people's participation in decision making to create their own future. The participation of young people in sustainable development efforts will determine the success of these efforts. Research, though, has shown that there is an attitude-action gap in young people. For instance, Mifsud (2008) reports that the overall attitude of Maltese post-secondary students towards the environment appears to be strongly positive, but they generally seem to perform little positive environmental action. One reason for this attitude-behaviour gap might be the way in which ESD is presented.

This research explores factors that encourage a change in behaviour in young people that have bridged the attitude-action gap and are actively involved in positive work for the environment. Whilst Tanner (1998) argues that "it is imperative that we understand how activists (informed, responsible activists) got to be the way they are" (p. 400), there has been, in fact, little research conducted on young people who are leaders in environmental action (Arnold, Cohen, \& Warner, 2009). The study aims to provide information and insights that will influence the development of more effective ESD programmes for young people - programmes that encourage young people to take the lead in sustainable development.

While both authors shared in the analysis of and reflection on the experiences gathered during this research, the use of the first person active voice was preferred over the passive voice in the writing of the research methodology of this paper. This was done to highlight that it was the main researcher (i.e. the first author) who, as a situated participant in the research, was doing the telling.

\section{Research methodology}

The story is a universal form of human sense making, and narrative inquiry values human experience as a way of generating knowledge and interpreting it. Narrative researchers collect and interpret these narratives to study how humans experience and understand the world (Gudmundsdottir, 2001). People reveal themselves to others by the stories that they tell. Narrative inquiry can thus help us to understand reasons for our actions, which are motivated by beliefs, desires, theories and values (Bruner, 1990). Narratives often seem able to give us understandings of people in a way that more traditional positivist methodologies cannot, because they recognise the value of the whole person and human life in its complexity (Freeman, 1997).

Narrative inquiry is not fragmentary and has thus enabled me to study the experiences of my participants in a holistic manner. I have positioned myself and my research within the experience-centred narrative research domain that involves "texts which bring stories of personal experience into being by means of the first person oral narration of past, present, future or imaginary experience" (Patterson, 2008, p. 37). I have chosen this position since I was interested in general experiences, themes within the stories, participants' thoughts and feelings and in building a relationship with participants in which they could share the responsibility of construction of the stories.

In this study, I was focused on trying to understand the life experiences of three individuals who chose to dedicate a portion of their lives towards the issue of climate change. The research problem can thus be seen as trying to think of the wholeness of 
these individuals' life experiences and to explore its complexity in the light of their activism towards climate change. I wanted to be able to see their past, present and future, what they thought and why they thought that way.

\section{Entering the field}

Most studies measure environmental behaviour through self-reporting, but the link between self-reported behaviour (or behavioural intentions) and actual behaviour can be quite weak. Various studies report that people claiming to possess pro-environmental attitudes often do not act accordingly (Finger, 1994; Schultz, Oskamp, \& Mainieri, 1995; Pelletier, Tuson, Green-Demers, Noels, \& Beaton, 1998; De Young, 2000). In studies that involve self-reporting, participants tend to report more engagement in proenvironmental behaviour than they actually do since it is easier to report such behaviour than to actually practice it, and it is also quite tempting to exaggerate positive actions (Schultz \& Oskamp, 1996). Participants would usually want to show the researcher how 'environmental' they are, and, thus, over-reporting is somewhat an inevitable outcome of self-reporting (Barr, 2007). Over-reporting is becoming more pronounced as environmental discourse is becoming more mainstream.

Stern (2000a) considers environmental activism - including active participation in environmental organisations - as an environmentally significant behaviour. Members in environmental organisations are expected to engage more in pro-environmental behaviour than the general public (Ellis \& Thompson, 1997; Hines, Hungerford, \& Tomera, 1986-1987; Olli, Grendstad, \& Wollebaek, 2001). If they are volunteering time and energy, it must be (at least partly) because they believe in the issue and in the possibility of change. Moreover, belonging to an environmental organisation is in itself a motivator towards adopting the group's shared pro-environmental behaviours.

My study was thus conducted with Friends of the Earth Malta (FoE Malta) - a local organisation affiliated with Friends of the Earth International (FoEI) and Friends of the Earth Europe (FoEE). I chose this non-governmental organisation (NGO) since, at the time, it was the only one in Malta that was involving young people in the fight against climate change. I did not only choose an activist environmental organisation, but from within I chose participants that had an activist role. Paying the organisation's membership fee does not imply commitment towards the organisation and its vision. There are different levels of membership within an environmental group, and, out of all possible types of membership, environmental activism is the most committed (Stern, Dietz, Abel, Guagnano, \& Kalof, 1999). Being an activist within an environmental organisation involves trying to actively influence policy making and public opinion to take and support environmental measures. Finger (1994) unsurprisingly found that environmental activism is directly related to pro-environmental behaviour. Emmons (1997) defined pro-environmental actions as "a deliberate strategy that involves decisions, planning, implementation, and reflection (...) to achieve a specific positive environmental outcome" (p. 35).

There are two starting points for narrative inquiry: listening to participants as they tell their stories and living alongside participants as they live their stories (Clandinin \& Connelly, 2000). I chose the latter and sought to first settle in, live and work alongside the participants and experience being an activist in an environmental organisation. During this time, I persisted in trying to become part of the group and join the group 
narrative. I recorded actions, happenings and feelings which became part of my field notes. I started the interviews four months after I first joined the group. This time spent living with the participants enabled me to get to know them first and also offered the participants the time and space to feel comfortable with the relationship between us. Trust is one of the most important aspects of the life story interview.

\section{Interviewing participants}

Narrative inquiry usually uses small numbers of interviewees, often sampled opportunistically (Squire, 2008). I was not interested in interviewing any member listed in the organisation's database, but in active young members. So I interviewed only those young volunteers that were committed to attending the climate change campaign meetings and actions. There were only three such volunteers - Charlene, Robert and Mary - who agreed to take part in the research.

The life story interview has different roles as a tool in narrative inquiry and provides a practical and holistic methodological approach for the collection of personal narratives (Atkinson, 1998). The narrative produced not only seeks to represent the storyteller, but also offers a way for the researcher and others to explore and interpret the personal world of the storyteller (Atkinson, 2007).

Prior to the interview, I prepared the participants by explaining what the interview was going to be about. I also gave them an empty timeline that they could fill with events that happened during their life - events that shaped their environmental values and influenced their choice to be active within FoE. The timeline allowed them to write down the year or how old they were when the event happened and to give a title or a short description of the event. They had time to think of these events on their own, at home and without any pressure, and, when they were ready, they gave me the timeline they had constructed. This timeline served as an initial basis for the interview. It enabled me and the participants to go into and discuss these events together in greater detail. These were events which the participants themselves deemed important without having any suggestions from me as the researcher. I also prepared a general interview guide with some open-ended questions that I discussed with the co-author of this paper. These questions addressed areas that did not feature in the timelines but which I wanted the participants to delve deeper into. The participants chose where they wanted their interviews to take place. For me this was important, because I wanted them to feel comfortable, 'at home'. So sometimes we met in their favourite coffee shop or at the FoE office, or in a public garden.

During the interviews, I guided the participants through the telling of their life story while recoding it on an audio tape. I allowed the participants to say whatever they wanted to say by refraining from asking a lot of questions or commenting about what they had just said (Riessman, 1993). However, when I thought that what they shared was just the tip of a big iceberg, I tried to elicit more by encouraging them to reflect on the events that had happened. The interviews can thus be described as semi-structured as the overall agenda was set by me, yet there was plenty of room for the participants' own personal agenda and spontaneous descriptions and narratives (Brinkmann, 2008). The direction of each interview was mostly determined by the participant's responses to ensure that the participant shared the role of deciding the course of the interview. I am aware of the fact that the stories elicited are very much a result of the interactions 
between me as an interviewer and the participants and that different types of interaction would most probably have produced different stories (Riessman, 1993).

\section{Producing narrative texts}

I transcribed and translated (from Maltese to English) all the audio recordings of the interviews. Although this took a painstakingly long amount of time, it allowed me to become more familiar with the narrative texts and feel closer to the participants. Transcription is also an interpretative process, and thus I also wanted to make sure that I had full responsibility of the interpretation. After transcribing, I omitted the questions asked during the interview, any utterances from my part and some repetitions. Content had to be restructured into sentences and paragraphs and reordered to make it chronological and thus to create a story which was clear and readable (Atkinson, 2007). This was important as people often do not conceptualise their stories in sequential categories, especially when they are speaking (Gready, 2008).

For both empirical and ethical reasons, to come up with narrative texts that truly reflect how the participants view themselves and their experiences and how they want to appear to the audience of the study (Freeman, 2003), I thus made sure that my relationship with the participants did not end with the interview. I gave them first the transcript and then the narrative text to review and change as they saw fit, thus valuing their intentions and agendas both during the interview and the production of narrative texts (Connelly \& Clandinin, 1990). This gave the participants the final say in what their life story will look like in its final form, giving them more power over the narrative (Squire, 2008). I cannot say that I was not hesitant about taking the narrative texts back to the participants as I feared that they would not like the texts and would want to drop out of the study. My fears were nevertheless unfounded, and all participants contributed to changes to the research texts.

The conversations between us did not stop when the interviews were finished, but I still remained part of the group, and the narratives evolved throughout the research process. The final product became the narrative texts which took the form of a firstperson narrative/story that retained the words and the voice of the participants. The narrative texts were thus created with the purpose of telling a story that provides the basic building blocks of narrative inquiry (Franzosi, 1998). Without a story there is no narrative. Sequence and meaningfulness were guaranteed through the following of the participants' life-course, but some 'non-story' material like descriptions and reflections were also included. This text became the essence of what happened to the participants, whilst presenting their perspective on, and understanding of, their lived environmental life. What the participants chose to tell me is what is most real and important to them and is what gives the clearest sense of their subjective understanding of their lived experiences (Atkinson, 2007).

\section{Analysis of the narratives}

There is no universal fixed approach in narrative analysis, but according to Plummer (2001), one of the central elements of narrative research is the analysis of key themes that help to organise the way a life story is told. These themes - that may be stories of events or particular thoughts and philosophies (Phoenix, 2008) - cluster around recurrent 
content in stories (Mc Adams, 1997). The identification of key themes does not imply a lack of value to the uniqueness of individuals and their stories, but an opportunity to identify and understand common patterns whilst taking into consideration differentiating aspects of lived experiences (Josselson, 2006).

In thematic coding, the researcher frequently begins with a list of themes known (or at least anticipated) to be found in the data (Ayress, 2008). In this study, the initial codes used came from a review of the literature and allowed me to identify tentative key themes across the stories. I also paid attention to the sequencing and progression of themes within the narrative texts (Squire, 2008). I moved back and forth between the narrative texts themselves and identified themes using interpretative procedures. Pieces of 'data' were decontextualised from the narrative text and recontextualised into a theme. Coding categories were reconceptualised, renamed, reorganised, merged or separated as the analysis progressed. It is through repeated reviewing and coding of the data that links between various codes were then made and the relationships among categories began to solidify (Benaquisto, 2008).

Every step of narrative research is always interpretive (Josselson, 2006): from choosing the participants; deciding what to ask them and what to delve deeper into; transcribing from speech to text; making sense of the transcript; deciding what to highlight and what to give less importance to and giving meaning to the narratives. Narrative inquirers work with an attitude of knowing that other possibilities, interpretations and ways of explaining things are possible (Clandinin \& Rosiek, 2007). The narrative texts produced can be considered as an 'open work' where meaning making is continued by those who read it (Moen, 2006). Looking at narrative texts in this way extends the many possibilities of interpretation.

\section{Analysis and interpretation of data}

This section of the paper outlines the key themes that emerged from the analysis of narratives. Even though the participants had the power to modify and interpret their experiences during the study, we - as authors of this paper - would like to point out that the final interpretation of the text is based on our understanding of these experiences.

\section{Values}

The values-beliefs-norms theory (Stern, 2000a) proposes that values influence our beliefs about the environment and the consequences of environmental degradation on the things and people we hold dear. Values influence pro-environmental behaviour (Thompson \& Barton, 1994; Stern, 2000a; Nordlund \& Garvil, 2002) and environmental activism. Although very hard to change, value changes may be the most effective means to achieve sustainable lifestyles. Society, culture and conditions in which we live tend to shape our values and thus behaviours.

It seems that today's children do not know how to really enjoy themselves. It is not their fault; it is the way in which life has changed since I was a child. Life is faster, and they have adapted to this lifestyle and the stress that it brings along with it. They do not even have the patience to read a book. (Charlene) 
Environmental values are often connected and intertwined with other values, such as values associated with family, community and economy that lead to pro-environmental behaviour (Jenkins, Bauer, Bruton, Austin, \& McGuire, 2006). Typical examples of such values are the post-war traditional values of 'non-consumerism', saving money, non-wastage and taking good care of material possessions. Charlene's traditional values were handed to her by her family not for pure environmental reasons, but rather for social and economic ones. Still these values are guiding her efforts to live a more proenvironmental life.

Funds are also quite limited. We are quite a big family with five children so money was always an issue. I am not grumbling, mind you, because we have always managed to live with what we have, we never wanted or wished things that were a luxury. I remember that, for many years, we did not have a car, and it took us quite some time and sacrifices to buy one as a family. You learn that you cannot buy everything and that some things are purely a waste of money. You also learn to appreciate what you already have. I have also learnt the importance of saving for the future, a concept that most youth nowadays do not even conceive. (Charlene)

Elgin (2010) would describe Charlene's experience as voluntary simplicity - a lifestyle that is outwardly simple and uses the minimum amount of natural resources and technology necessary. According to Elgin (2010), this way of life is inwardly rich in its appreciation of simple experiences and pleasures. However, not everyone is happy to cut back on life's comforts and having to do with less. Doing this is often seen as a sacrifice and, according to Kaplan (2000), describing sustainable living in terms of making sacrifices is bound to be counterproductive.

Contrary to the dominant social paradigm of disposability, Charlene is also guided by traditional values in the way she appreciates and takes care of her things, with the notion that they will last longer if taken care of.

Being the oldest child, I was always quite responsible. I take really good care of everything that I have, and I appreciate everything. Even when I receive a present, I try to conserve the wrapping paper, so I can use it some other time. I still have toys from when I was a child that are still in their boxes. I want everything to be as it should be. (Charlene)

This quote provides evidence how a value is seamlessly translated into pro-environment behaviour. A person that sees value in taking care of personal material possessions is more likely to understand, respect and take care of the planet's resources so that they will last longer. Thompson and Barton (1994) identified two motives for the adoption of pro-environmental behaviour:

(a) anthropocentric motives - based on the belief that the value of the environment is relative to its importance and usefulness to humans;

(b) ecocentric motives - based on the belief that nature should be preserved because of its intrinsic value.

Thompson and Barton (1994) argued that individuals engaging in pro-environment with anthropocentric motives are easily inhibited by other human-centred values, such as time-efficiency and material quality of life. Their studies show that the correlation between pro-environmental behaviour and anthropocentric motives was either negative 
or not significant. This was corroborated by Mary's perception that people often give up doing positive environmental actions because they think that they will interfere with their quality of life or become a hassle.

Often, people still want to retain the quality of life they have, and, at the same time, they want to change because of future generations, because they know that this is a moral issue, in a way. Some people are just not ready to change. For example, even though separated waste is collected from in front of each house, a lot of people do not bother to separate waste. (Mary)

An ecocentric perspective towards decision making is one that takes into consideration the interests of the natural environment even when there is no apparent instrumental value to humans (Eckersley, 1992). As opposed to anthropocentric individuals, according to Thompson and Barton (1994), ecocentric individuals are more likely to show proenvironmental behaviour, even if it requires some sort of sacrifice from the individual. This is clearly demonstrated by Robert's attitude towards driving and by his conversion to vegetarianism.

I really do not like the fact that, when people turn eighteen, they become obsessed with buying a car, and, so, when I turned eighteen, I did not do it, and I actually still refuse to buy one. Maybe my stubbornness is because of laziness, but I'd like to think that it is because I don't want to increase pollution. I still get into my friends' cars, but I also use public transport a lot. (Robert)

I started understanding, very slowly, the logic and importance of cutting meat from my diet. ... I completely eliminated meat and started eating fish and vegetables. Then I took a decision that I would not eat meat anymore. It was not that difficult actually. In summer 2008, I also stopped eating fish as I started seeing that there was a big problem with tuna, and the fish that I was actually eating the most was tuna. I was also realising that there were a lot of endangered fish that I was eating. My mother was buying fish that were coming from all parts of the world, like Canada, for example, to try to adapt her cooking to my diet. So I was actually making things worse. (Robert)

The values that individuals attribute to themselves, other people, other living organisms and the environment also guide their environmental decisions and behaviour (Stern, Dietz, \& Kalof, 1993; Stern \& Dietz, 1994; Stern, 2000a). According to Stern (2000a), pro-environmental behaviour is activated by beliefs that environmental problems will threaten things and persons that are valued. Stern and Dietz (1994) identified three value-based environmental concerns and termed these concerns as egoistic, socialaltruistic and biospheric.

Egoistic concerns are based on the belief that the self has more value than other people and other living things. People with high egoistic values are expected to be concerned about environmental problems when the environmental damage is perceived as a threat to the self. They engage in pro-environmental behaviour when this provides personal benefit. Social-altruistic concerns are based on the belief that humanity has more value than other living things. People with high social-altruistic values are expected to be environmentally concerned when there is a perceived threat to other people. They 
engage in pro-environmental behaviour when it benefits others. For instance, Charlene is concerned about the environment that will be inherited by her future children.

Even if I happen to never see the fruit of the work that I do or that FoE does, I would like to think that my children will have the opportunity to enjoy the natural environment, in the same way that I have enjoyed it before them. (Charlene)

Biospheric environmental concerns are based on the belief that all living things have an intrinsic value. Individuals with high biospheric environmental values are concerned when this intrinsic value is threatened. They engage in pro-environmental behaviour even when this does not have an apparent benefit for the self or other people. Mary exhibits such biospheric values and concerns in the way that she has always taken care for animals since she was a child.

Once, before going to school, I heard a cat crying, and I wanted to go and look for it, but my mum did not let me as I was late for school. You can imagine what a day I spent. I could not concentrate at all at school. I was just thinking of the cat the whole day, and, then, when I went back home from school, it was still there. I could hear it, and then I found it amongst some vegetation in the yard. Obviously, after so much angst, we kept it as a pet. I also had a pigeon that came to me once, and I also took care of it. (Mary)

Stern et al. (1993) conclude that people engage in pro-environmental behaviour as a result of a combination of different values. Individuals do not just harbour egoistic, social-altruistic or biospheric values exclusively, but have differing levels of each of these values, which lead to a combination of concerns and serve as guidance for personal behaviour. Furthermore, Dietz and Stern (1995) suggest that, when taking decisions, people may give different weight to the various values depending on their role and circumstances at that particular situation. Poortinga, Steg and Vlek (2002) claim that these relationships between values, environmental concern and behaviour are far more complex. Decisions may not always be the result of thoughtful decisions. In certain situations, when required to take quick decisions, the influence of values is lessened or the importance which we give to different values is altered (Dietz, Fitzgerald, \& Shwom, 2005).

\section{Self-efficacy and locus of control}

The locus of control represents an individual's perception of whether s/he has the ability to influence life events through her/his own behaviour (Hungerford \& Volk, 1990; Newhouse, 1990; Ozmete, 2007). Individuals possessing an external locus of control feel that luck, destiny or powerful others shape their future. Such individuals believe they are powerless and that the outcomes of situations are beyond their control. On the other hand, individuals having an internal locus of control perceive themselves to be in control and that their actions can bring about change and affect the outcomes of situations.

If people feel that they can control some feature of their external world, they are more likely to work actively towards improving it (Cleveland, Kalamas, \& Laroche, 
2005). According to research, individuals with an internal locus of control are more likely to engage in pro-environmental behaviours (Hines et al., 1986-1987; SmithSebasto \& Fortner, 1994; Hwang, Kim, \& Jeng, 2000; Bamberg \& Moser, 2007). For instance, an internal locus of control has been found to specifically influence energy conservation behaviour (Balderjahn, 1988) and recycling (McCarty \& Shrum, 2001; Shrum, Lowrey, \& McCarty, 1994). Yet, some studies (for instance, Hamid \& Cheng, 1995 ) contradict this.

The participants' narratives indicate that they all have a strong internal locus of control. Robert believes that through his actions with the local council he can help to improve the area in which he used to play during his childhood.

I am, at the present moment, reviewing a development plan of Wied Blandun that was sent to me by the local counsellor in charge of its upkeep. This is the area in which I used to play when I was younger. I know what the problems in the area are, because I have grown up there. Some areas are derelict and used by drug addicts, so cameras have to be placed in strategic locations. The little undeveloped land that remains needs to be protected and more indigenous trees should be planted. The area will hopefully regain its former glory and be used in a positive way for and by residents. (Robert)

Charlene believes that she can improve ecotourism in Malta by helping farmers to apply for European Union funding to upgrade their farms.

I am, at a point, where I would really like to do something. I would like to make things change and to see more locals and tourists alike appreciate Maltese nature and its products. In fact, I am working on a project with a friend of mine, and together we are trying to secure some funds for a particular farmer in Gozo. He has asked us to help him to make his farm more attractive to tourists and locals to come and visit. (Charlene)

Self-efficacy is the belief in a personal capability to achieve a goal. Believing that you can perform an action will increase your chances of actually doing it. Mary has shown high self-efficacy by significantly affecting the environment at her workplace with regards to recycling, even convincing others to participate (Stern, 2000b).

I remember that one of the first things that I did when I joined the office was that I spoke to my boss and told him that it would be a good idea to start some waste separation; at least we start from paper, because paper is something that in an office is used all the time. I used to discuss a lot with my colleagues during coffee breaks, in the kitchen, and there were people that used to really try to convince me otherwise telling me, "But why are we going to go through this hassle to do these things?" There was one particular person that used to say that our separation would be useless as rubbish trucks still mix everything together. I used to tell them that, if we take the paper directly to the collection site and we see that it actually gets there, we would be sure that our efforts were not in vain. (Mary)

People who are unmotivated towards the environment often have a sense of helplessness regarding the environment (Pelletier, Dion, Tuson, \& Green-Demers, 1999). Individuals with low self-efficacy are still concerned about environmental issues, but when challenged 
with complex issues like climate change, they do not know where to even begin, and the tendency is to do nothing. In fact, Kaplan (2000) found that people do not engage in pro-environmental behaviours not because of a lack of interest or concern for environmental issues, but rather because they are inhibited by a sense of helplessness. This is understandable since most environmental problems are large and complex with no immediate and simple solutions, so people feel helpless on their own. People with an external locus of control and low self-efficacy, need to be convinced that there are things that they can do to contribute towards the solution of environmental problems. This can be done with the help of campaigns that illustrate how they can help the environment in small yet significant ways. In fact FoE Malta launched a number of projects which directly target such individuals.

One such project was called “The Climate Is Changing ... Are You?”. Rather than just frightening people about the effects of climate change, the project aimed at informing the public through posters, leaflets and media clips about climate change and what individuals could do to mitigate its impact, thus empowering people to look for and become part of the solutions. When people learn about, understand and engage in proenvironmental behaviours, they will feel more competent about the solutions and are, then, more likely to adopt such behaviours (De Young, 2000). Encouraging specific, concrete actions that are effective, even if small, is a promising initial approach because everyone can do this easily, and the collective result is quite considerable.
Since becoming a climate change campaigner, I have also become more aware of the issue and my energy consumption. I am very careful with not wasting energy, wherever I am. I am always the one that switches lights off all the time, bugging my family incessantly. I know that it is a rather small contri- bution, but I believe that first steps are very important. If everyone had to be conscious about their energy consumption, the problem would be very much reduced. (Charlene)

Experiences with this group revealed that even though the internal locus of control seemed to dominate, both internal and external dispositions co-exist within young environmentalists. Their experience with the group dynamics and the local and international political scene taught them whether and to what degree they can exert control over situations. For instance, Robert gets many ideas from his involvement with Young FoEE, but he feels that he cannot implement them because of the really small number of volunteers. He also feels that his ideas are often shot down by others. On a more general scale, the environmentally inappropriate behaviour of large corporations and the government makes the participants feel powerless at times, stirring up feelings of anger that are not only directed towards the entities and the system, but also towards their sense of helplessness.

In Malta, we speak a lot about ideas like ecotourism and lately ecoGozo, but, often, nearly nothing gets done, and people do not even get to know about these things. (Charlene)

Even public consultations are a bit of a sham in Malta, where people do not have a real opportunity to give their opinion, like having a consultation over one day in the morning, the peak time when people work. (...) The Maltese way of doing things ensures that the people with the money and power are 
the ones who always acquire even more, and the people that have neither remain empty-handed. (Charlene)

When I was at university, I had to find some part-time work because I needed money, and so I started working with a multinational burger company. (...) I used to be disgusted by the amount of rubbish generated and food that is thrown away. The amount of packaging used, for example, was horrific. (...) The room in which we used to throw the rubbish used to be literally packed till the roof. I did not last long as I quit from working there. (Robert)

Then recently, there was the new power station issue. A new power station. And it is still going to be using fossil fuel and, thus, old technology. There were also a lot of intricacies in the way the contract was given. All of this dampens any hope that things are going to change in Malta. We have been playing around too much on the wind energy issue. First, having turbines on land was a definite no, and then it was a yes and then a maybe. It is true that we have little space on which to locate the wind turbines, but, still, all of these games tend to confuse people. (Robert)

Green jobs are really limited in Malta, not just in the governmental sector, but also in private industries and companies. I believe that a lot needs to be done about jobs in this sector. There is a gap that we need to try to fill up. (Mary)

This sense of helplessness is relieved when there is an actual contribution to a successful outcome, and the volunteers again gain confidence in their power and ability to bring about change. Political activism requires loads of energy and perseverance, but, at the same time, it can make you feel that you are the agent of a 'revolution' - of change!

At least we reached a point where our goal was actually mentioned at parliament. Other NGOs were also agreeing with us on the media. It was very positive. I think this was one of the top things that we managed to achieve through the campaign, and I think everyone was really proud of that moment. (Mary)

Organised group activity can build a sense of collective efficacy (Oskamp, 2002). Even though individual action is important, organised activism is frequently necessary when dealing with large-scale issues since the culprits are very often governments or powerful corporations, against whom, individual action would go unnoticed (Oskamp, 2002). Being part of an international organisation brings about the realisation that other groups in other places are also working for the same goals. Knowing that other young people are successfully achieving results may reduce the feelings of helplessness and the notion that nothing can be done (Kaplan, 2000).

... the first Young FoEE summer camp. (...) It was really awesome, because even though we are still young, we already have lots of things to share. A camp like this mobilises young people and enables them to learn from each other. It is a source of inspiration and motivation to try bringing about change around you. Networking is also important in such events, and we 
started to work together to plan actions for the upcoming Copenhagen climate change negotiations. (...) I was so energised that, as soon as I came back from the conference, in January, I coordinated the climate change campaign before the Big Ask campaign started. (Robert)

\section{Knowledge}

Whether and how we react to knowledge about environmental problems depends on whether we understand and accept that knowledge, which in turn depends on our past and present experiences, our sensitivity and so on. In other words our reaction towards new knowledge will depend on our perception of it. Mary, in fact, noticed that during her university course not everyone reacted to knowledge in the same way that she did.

I was always usually the one most irritated during lectures when I hear about some things that are not carried out as they should be in the environment sector, as these finally would have an effect on us. (Mary)

This difference in reaction might be rooted in the different values held by Mary and the other students. Values may function as filters for information. Information that agrees with our values tends to be accepted while information that clashes is rejected. Habits might also result in selective attention. People are more likely to consider new information that is already in line with their behaviour than information that will require changes to their habitual behaviour. Ignoring information that challenges our comfortable lifestyles is a coping mechanism that makes living with incongruencies less difficult (Jensen, 2006).

\section{Experiences in nature}

Tanner (1980) tried to identify significant life experiences in conservation activists and leaders and claimed that "youthful experience of outdoors and relatively pristine environments emerges as a dominant influence in these lives” (p. 23). All three participants in this study have vivid childhood experiences in rural areas where they bonded with the natural environment. For Charlene, the time spent at her grandparents' farm that she visited regularly as she grew up was a very important memory.

I have many memories of this time, such as when I tried to get on my grandfather's mare, she threw me off. My siblings and I spent our childhood running in the fields picking capers and flowers and looking for snails. This was the best time of my life, and it will not come back. These things have sort of ended nowadays. I wish I had the time to relive those moments. (Charlene)

Even for Robert being in the family fields when he was a child was something that he thought was important in shaping his love for nature.

My father has fields in Marsaxlokk, and, ever since I was a small boy, I used to spend time in my father's fields, playing. It was a very happy time in my life. (Robert)

Mary's family did not own fields, but they still lived in an area close to fields, and her childhood play was surrounded by these fields. 
When I was a child, I used to live with my family in Xg'ajra. There was a really big field in front of our house, and the whole area was very rural, with passageways that lead to the sea. When I looked out, in the distance I could see the sea. My brother and I used to spend a lot of time playing outside and in the fields. My brother was always a little bit more naughty and daring than me, and he used to jump over rubble walls. (...) This contact with nature when I was a child was very important in shaping who I am today. It was a very happy childhood, and I look back on it with nostalgia. (Mary)

It seems that experiences of engagement with the natural environment during childhood cling on to the individual shaping his/her subsequent environmental path. It is easier to love what you know through a cherished association. Regular positive experiences in the natural environment allow children to form a relationship with it, encouraging a love of nature (White \& Stoecklin, 2008) and the fostering of pro-environmental values through regular positive experiences in nature (Chawla, 2007). Other researchers have noted that significant life experiences in natural settings are important in developing positive perceptions of nature, positive environmental attitudes and, more importantly, environmental action (Palmer, 1993; Bögeholz, 2006).

Wells and Lekies (2006) found that experiences in the natural environment before the age of eleven were the best predictor of adult environmental behaviour. Moreover, they claim that although domesticated nature activities (like caring for plants and gardens) fostered pro-environmental attitudes, their effects were not as strong as participating in 'wild' nature activities, such as camping and hiking. However, the study by Wells and Lekies (2006) did not consider post-childhood experiences. Adolescent, youth and adult experiences might also be important in instilling a love for the natural environment. Robert remembers with nostalgia not only his childhood carefree days in nature, but also his teenage years with his friends.

I live in Fgura, in front of the only agricultural fields left, and I think that this has allowed me to appreciate nature and the environment a little bit more. When I was a teenager, my friends and I used to play in the fields in front of my house. Every Saturday morning we used to go and spend whole days running in the fields. (Robert)

Charlene also speaks enthusiastically about her experiences in nature when she was researching for her dissertation.

It was a really fantastic experience that I would definitely try again. I was in contact with animals, milking sheep and collecting eggs. I held a chicken with my hands and for me, touching an animal is already a valuable experience in itself. My boyfriend came with me, and he participated in things that he had never imagined that he would do, not even in his wildest dreams. I did not think that he would be such a sport, being from an urban city and lacking any contact with nature. But he definitely enjoyed it. It was literally a wow experience, even my boyfriend agrees. And that is saying something. (Charlene)

The experience of nature's beauty leads people to regard nature with respect and reverence because it helps them to realise its intrinsic value. Robert appreciates the opportunity he had to travel and experience living in nature - something that is very difficult to do in Malta. 
I went to a youth exchange in Romania on Green Therapy! The programme was conducted in nature all the time, and the feel of it was so intense. (Robert)

For Mary, the contact with nature also instils in her an experience of freedom.

I remember that I really used to enjoy the fact that I was often outside and not enclosed at home. I really loved the open space and the sense of freedom that it gives you. Today as an adult, the sense of carefree days may not happen so often although the sense of freedom is still with me, and, thus, I tend to appreciate such opportunities much more. (Mary)

Ironically, we live in a time in which many people experience nature virtually though online information or nature documentaries rather than direct physical contact with the environment. Pergams and Zaradic (2006) reported a significant relationship between a steady annual decline in visitation to National Parks and an increase in virtual entertainment such as playing video games and surfing the internet. They suggested that in childhood, outdoor activities are, in fact, being replaced by such virtual activities. A study of primary schoolchildren in the UK revealed that children aged eight and over were better at identifying characters from Poke'mon (a card-trading game) than familiar organisms such as a beetle (Balmford, Clegg, Coulson, \& Taylor, 2002). This disconnection from the natural environment was termed 'nature-deficit disorder' by Louv (2005). Today, most children and youth live in urban areas and experience artificial environments more than they do the natural outdoors. This was duly noted by Charlene.
I think there should also be more recreational areas where children can play and be in contact with nature rather than having artificial playgrounds with plastic floors, plastic houses and plastic everything. If people have more opportunities to enjoy the natural environment, then they will start caring more for it. (Charlene)

At the end of a school day, most Maltese children are shuttled from one activity to another - ranging from football, dance and drama classes to piano and private lessons and their little free time is then spent in front of the TV or a computer screen. With all the good parental intentions most children are being subjected to a hectic, artificial and electronic childhood that is interfering with their holistic development.
Today's children cannot appreciate these things. My younger siblings did not experience this as there is quite a gap between my sister and I, and the twins. When the twins where young, my mother had to go to work, something that she did not have to do when I was a child. So she had much more time to spend with my sister and I, and we often spent that time outside, near the beach or in the countryside. (...) Sometimes though, I actually feel sorry for them as their childhood was much less fun compared to mine. They spend most of their free time playing on the computer or watching television. (Charlene)

The number of studies showing that environmentalists tend to report significant childhood experience in nature leads one to assume that the lack of such experiences in the lives of today's children may negatively impact the availability of environmentally responsible citizens. The introduction of ESD programmes in a number of schools can be viewed as step in the right direction to address this lacuna. However, the type ESD that 
is really needed should go beyond the school gate. The problem with most current ESD programmes is that they try to feed knowledge and demand responsibility and action before children have been allowed to develop an intimate relationship and connection with the natural world (Sobel, 2008; White \& Stoecklin, 2008). In the past, Maltese children could experience unstructured ESD at weekends and after school with their family or friends, in the fields and/or in natural settings. Nowadays, this time seems to have been taken up by other activities.

On winter Sundays, up till the age of about fourteen, I used to go hiking and camping with my family in nature. We often used to go to Buskett or Chadwick Lakes for our Sunday outing and to other places in the countryside. It was a very relaxing time spent with my family. We used to play games such as hide and seek. (...) Sometimes we used to go as a whole family with aunties, uncles and cousins. We used to go to Kennedy Grove, riding bicycles, running and playing. These were memorable times in my life, and I really treasure them. These were also times that bonded us closer together as a family. (Charlene)

There is huge potential for parents to both instil this love of nature in their children and spend valuable time with them (Cleary, 2007). Positive direct experiences in nature with a significant adult, such as a parent or a grandparent, stimulate a love for nature, a genuine interest in environmental knowledge (provided in formal ESD programmes) and eventually generate environmental action (Palmer, 1993; Chawla, 1998, 2006; Kals, Schumacher, \& Montada, 1999; Schultz, 2000; Sobel, 2008; Wells and Lekies, 2006; White \& Stoecklin, 2008).

Young children also have a natural affinity for animals (Sobel, 1996). Animals are an infinite source of wonder and curiosity for children. Taking care of animals at home can also help to promote an attitude of care and responsibility towards living things.

We always had pets at home, either a cat or a dog or anything really. We really loved them, as a family. (...) A pet teaches you how to care for something living. It takes a lot of care and patience to have a pet at home. Especially if you have a dog, you need to feed him, play with him and take him out for walks. I was always interested in animals. (Mary)

Having a direct contact with nature allows you to appreciate it more. There are children that have never seen live animals. I have always been in contact with animals, and it must be the reason why I love them so much. (Charlene)

Animals and children seem to have a close connection, and, in fact, studies of small children's dreams reveal that about $90 \%$ of their dreams are about animals (Patterson, 2000). Children have the ability to interact with animals in an instinctive way. They often talk to them as if talking to a friend and invest in them emotionally.

I remember that once, in our garden, we had an insect pupa, and it fascinated me so much that I used to go and observe and keep an eye on it. Until one day it wasn't there anymore. It vanished. I realised that obviously it had turned into a butterfly. Even though I knew that, I was still very much in awe of it all. (Mary) 
The experience of nature is also an important motivation for people when they involve themselves in the environmental political sphere (Trittin, 2009). This experience does not have to be positive; negative experiences can also instigate political actions. For instance, environmental activists often mention the loss associated with the destruction of their childhood special place as a reason for their activism (Shaw, 2000). This is certainly Robert's experience.

Through time, I watched a lot of fields in Fgura being destroyed. This has pained me, and, in fact, I have become part of a committee within the Fgura local council with the aim of conserving Wied Blandun, which is a valley of ecological importance. (Robert)

\section{Role models}

According to the social learning theory, behaviours can be learned by observing others, who are referred to as 'models' (Bandura, 1977). When asked what prompted their environmental commitment, environmentalists mention special childhood places in nature and family role models that showed them the value of the natural world (Chawla, 1999, 2007). This trend was also confirmed by Berkowitz (1987) while investigating a group of people who initiated grassroots community organisations. Children need to see significant adults respecting and loving the environment in order to develop that same respect and love.

The participants in this study also had or still have a beloved family member that exposed them to nature and taught them to appreciate life in all its forms. Charlene's father has always been a lover of nature, and she realises that his attitude towards it was important in shaping her own environmental attitudes and values.

I would like to think that I have inherited my father's character. He is a lover of nature. Every spare time that he has, he goes out somewhere where there is some greenery. He has always filled our home with life, building a greenhouse, having pets and other animals. I think that he has influenced me a lot, and my efforts to improve the local environment would be worth it, even if they were just for him. (Charlene)

Through what they attend to with care or fascination, parents indicate to their children what has value. Mary's parents are keen gardeners, and, through gardening, they have influenced Mary's perception of the natural environment.

My parents are really into gardening, and we had quite a big garden with trees. They actually also extended it, to have more space for trees. They have all kinds of plants at home. I was always surrounded with plant life and learnt a lot about nature through them. I am not really knowledgeable about plants and plant life, and I really wish that I knew more. I really admire people who are really into nature and know the names of plants and where they grow and their characteristics. I really enjoy listening to explanations about plants and how they grow. I am always eager to know more and more about these things. (...) My mum also used to listen to a lot of radio programmes about growing plants, so these were always at the background, and I guess I was subconsciously listening to them as well. It is later on in 
life that you realise that these things leave an impact on you, even though they do not seem so important at the time. (Mary)

Through their own relationship with nature, significant adults communicate nature's value and, thus, promote the child's interest and care towards it (Chawla, 2007). Apart from giving a sense of value to nature through her care for plants, Mary's mother tried to teach her that insects are an important part of nature and that they are not scary. Mary sees her mother's efforts as important in shaping her perception of the environment.

I am really afraid of insects, and my mum often used to send me cutting fresh herbs from the garden for cooking. I used to be really afraid, having to pass through so much vegetation, always with the fear that an insect was going to fly on me. Later on, I discovered that mum used to send me cutting herbs on purpose, to reduce my fear of insects. I think that the family's attitude towards nature and the environment in one's upbringing is very important to shape one's values. I was always surrounded by a love for nature and living things. Maybe that is why I have grown up with this same love. (Mary)

According to Kollmuss and Agyeman (2002), nature experiences and environmental family values are meaningful to children, whereas environmental role models such as friends become important for adolescents and youth. Peers were mentioned by Robert as a factor which helped him to turn to vegetarianism.

I also had some positive peer pressure as well, from some friends who are members of Graffitti, a radical NGO in Malta and from other FoE members. (Robert)

Peers were also found to be influential in convincing participants to join FoE and becoming authentically involved later on.

\section{Formal education}

Formal education is often assumed to increase an individual's concern about the environment (Ignatow, 2006). This assumption is not totally unfounded. Klineberg, McKeever and Rothenbach (1998) reported that "younger and better educated members of the public do indeed appear to be more concerned about issues of environmental quality and are more committed to environmental protection" (p. 749). A number of studies reviewed confirmed a positive relationship between environmental attitudes and level of education (Tognacci, Weigal, Wideen, \& Vernon, 1972; Hines et al., 1986-1987; Eckersley, 1989; Aytülkasapoglu \& Ecevit, 2002).

I think that. in my case, though, it was education that had the greatest impact in shaping my environmental values and beliefs. (Robert)

Although ESD has always featured in various subjects, in Maltese schools, it has never been a compulsory component of the curriculum (Pace, 1997). The introduction of ESD in the curriculum as a cross-curricular theme is only a recent development (Ministry of Education, Employment and the Family, 2011). For Mary and Robert, the subject that seems to have helped in transferring knowledge and shaping their attitudes was geography. 
Geography has satisfied my curiosity of the world. (...) I like especially the human impacts part of geography. It makes you realise how much things are connected and how if you change one thing, it will have like a ripple effect on so many other things. (Mary)

(...) probably choosing geography was quite a coincidence, since it was offered in conjunction with the subject I really liked. (...) Then, I continued studying geography and history at Junior College as advanced level subjects, and $I$ also went on to read for a degree in geography and archaeology. I guess studying geography was a very constant feature in my life. In geography, you always learn about environmental issues, like global warming and other such issues. I think that as a subject it gives you a wider perspective of the things that surround you or rather the environment. (Robert)

The participants in this study all have a first degree. One participant also has a Master's degree (Robert) and another is reading for one (Mary). They see their studies at university as a period of consolidation of their interest in environmental issues.

At the end of my course, I started asking myself what was going to happen once I finish university and how I was going to get more involved in the area of environment. Geography, being a vast subject, had prepared me to open up to different aspects of issues. (Mary)

Then, at university, we started a credit on sustainability, and one of the sessions was on alternative tourism and ecotourism. I realised that I had found what I was looking for. (Charlene)

From my experience at university and FoE, I started realising that it was not waste that was interesting me the most, but I was becoming more interested in aspects of human environment. I met up with an expert from university, and we discussed a lot about the United Nations, conventions, education for sustainable development, and I started opening more to what is happening on an international level and what is not happening in Malta. From there, I had a growing interest in sustainability issues. I started reading more to fine tune what I really wanted to focus on. I decided that I did not want to read for my master's degree with the University of Malta. I found a degree on sustainable development with a foreign university. I am finding it really interesting, because it touches on a lot of topics, and I am the sort of person who prefers to know about many different things, without needing to get into depth. I prefer to have a sort of global perspective of different issues, and, in this degree, I am having the opportunity to study different modules that have got to do with sustainable development. (Mary)

However, Mifsud (2008) points out that although there is a correlation between knowledge and attitudes and between attitudes and action, there is no significant correlation between knowledge and action. This might be the result of the predominant contentbased teaching methods that are structured around teaching as opposed to learnercentred approaches that depend on learning. 


\section{Non-formal education}

An important but generally forgotten aspect of ESD is environmental political education, which focuses on how changes can be achieved via political activism directed at governments, international organisations and corporations (UN, 2004). This seems to be exactly the type of non-formal education that the participants are receiving from FoE - an education that is also made available through training projects in other countries. These projects seem to impart a sense of partnership with others and a widening of perspectives about a variety of global social and ecological problems. However, the dominant benefit reported by the participants of this study is the educational impact of first-hand actionoriented activities they experienced.

To help us to start off with the campaign and to strengthen the organisation, we took part in a capacity building project. This was a training project that took place in England and some other countries that were involved in the project. (...) This was one of the most challenging moments of my experience with FoE, and it helped me to grow a lot. During this project, I had the chance to take part in training and, then, to apply what I had learnt here in Malta. I went for this training with another person from the board, so that we could support each other. It was a really good training, in which I learnt about areas that the university course that I followed did not present. I learnt about things that are important in practice, like communication, public relations, campaigning, activism and about strategies such as how to push for an agenda, how to approach different types of people, different sectors, like the government or the public. This opportunity was like a springboard to me. It also enabled me to relate aspects of the Maltese society with others from other countries and helped me to start seeing the common aspects and differences between FoE in Malta and FoE in other countries. I learnt about the particular issues that each organisation fights for and about different cultures, how they influence environmental issues. It was a wonderful experience for me, and I think that it was during this time that I really felt that FoE is MY organisation - this was and still is my kind of thing. (Mary)

The conference was a turning point for me. I experienced being a vegetarian for the first time. I also met people who were hard core environmental activists, and I did some activist work myself, like being body painted in front of the parliament in Berlin. I also learnt a lot from people, during workshops and lectures. Some were actually experts in the fields of energy and climate. It was an excellent experience for me. One that has changed me, I would say. (...) Also, in June, I went together with three other members of FoE Malta, to the YouPEC 2008, in the Netherlands. The theme for 2008 was about the sustainable consumption of resources. We followed workshops, participated in discussions and gave and gathered ideas for projects in open space sessions. We also met with a lot of environmental activists, especially from Scandinavia and the Netherlands, who are radical on climate change and consumption in a way that has definitely not yet been seen in Malta. (...) I learnt a lot about the different projects that people are doing in their countries. You realise that you are not alone, no matter how lonely you might feel in your respective country. (Robert) 


\section{Informal education}

In the 1990s, the Secretariat for the Environment (a government agency), launched the Xummiemu campaign targeting school children. The campaign aimed at developing pro-environmental behaviour through a well planned media spots featuring Xummiemu a cartoon hedgehog adopted as the Secretariat's mascot (Pace, 1997). The campaign also seems to have strongly influenced all three of the participants.

When I was about nine, there was the Xummiemu campaign. It was an excellent campaign against littering especially. I was exposed to it at school, through the student magazine (...) and through the media. As kids we were really on to Xummiemu. (...) We used to be like brainwashed against littering. If other kids saw you picking up some rubbish, they used to tell you, "You are like Xummiemu." I was so into it that I used to actually pick up litter near my house from the street. My mum was not so keen though, she did not like seeing me pick up rubbish with my hands. It was not very hygienic, but I still did it. (Mary)

When I was seven, there was the Xummiemu campaign, and I remember that I was crazy about the Xummiemu books. (...) The campaign also featured good promotional material like stands at the Malta Trade Fair, and I also remember the letters that I used to receive from the Klabb Xummiemu. There was also a section about the campaign on the student magazine. (...) The campaign and its promotion must have been really good as I remember nearly everything about it. It has probably influenced me, even if just a little bit. It created a lot of awareness against doing certain things. The emphasis was on littering. I remember all kids my age being really obsessed about not littering. It was definitely a good brainwash. (Robert)

When I was in primary school, I was given an application to become a member of the Klabb Xummiemu, and my mum filled it up for me. I used to receive a lot of things from Xummiemu, and I still have the birthday cards that I received from him. The Xummiemu campaign was quite successful, and the character was portrayed as a friend and someone that young children could associate with the environment. There used to be a lot of activities for children in the campaign even though I do not remember ever going to any of them. It was sort of a start in environmental education campaigning, and it was successful enough to have all kids really keen on not littering and actually collecting litter. (Charlene)

Robert also highlights the power of the media when he recounts that a documentary about hunting in Malta pushed him and other young people to do something about the issue.

This year, I went to see the documentary "Birds, Bins and Bullets" at the cinema. This documentary is about a group of English birdwatchers that worked together with the police and volunteers from BirdLife Malta to help in the fight against illegal bird hunting. I was so impressed by the volunteers whose cars were badly damaged and also shot at that exactly after the documentary had finished I contacted the conservation manager and told 
him, "I want to help you." BirdLife then organised a meeting for new volunteers, so the documentary must have touched others like me, and, one or two weeks later, I was helping them in the spring camp. (Robert)

\section{Personal challenges in environmental volunteering}

The personal challenges of individual volunteers influence their capacity to work with an organisation. Volunteering exerts additional pressures on volunteers who are already finding it difficult to cope with life's pressures, such as family, work and professional development.

I think that, in Malta, we have quite a problem with volunteers. Everyone seems to be really busy, including the coordinators. FAA - another NGO for example, has a coordinator who is a full-time volunteer. But we do not have that. Our reality is quite different. Our coordinator has a full-time job apart from his voluntary work, and it is quite difficult to manage giving one hundred percent in both. (...) Sometimes, even I feel like giving up, and, every now and then, I spend some time when I am not active, either because I cannot keep up with things or because I am discouraged. (Robert)

Maybe the climate change law is achievable, and we need to do more events, but we cannot do them with all the things that we have on our hands. Volunteers work, have relationships, children, and you realise that there is a limit to how much things we can do. Everyone pitches in, whatever they can and you just need to appreciate that. (Mary)

Sometimes volunteers are assigned too many tasks, and they experience a 'burn out'. This usually happens to volunteers who find it difficult to say no and continuously undertake more and more work and responsibilities, even though they know that they cannot cope with them.

Sometimes it becomes difficult to keep up with everything. I usually attend meetings regarding Young FoEE as I am in the steering group, meetings to plan conferences and actions and so on. Sometimes I become overloaded, and, then, I switch into slow mode. (Robert)

Teamwork is very important in an organisation, and members often need to feel part of a team to be able to give their utmost in a project. This is exactly the case with Robert.

I was working on a photographic exhibition on climate change, on my own, but it did not work out. When I am not working in a team, I become lethargic, like when you feel really hot and feel like you cannot absolutely do anything except sleep, and lately the team-work has been missing a bit from FoE Malta. (...) When you have a strong team, actions will work much better. (Robert)

Teamwork is an important concept in organisations, but it is not always easy to achieve it. Teamwork does not only mean working in a group, but it implies nurturing a sense of oneness and the belief that the organisation's mission and vision can best be achieved by working together. Consequently, a very challenging time for a volunteer is when s/he experiences little or no sense of achievement after giving so much time and energy towards the aims of the organisation. 
Sometimes the results that I see from our work are minimal. I don't know if I am being pessimist in this case. It could be, because I am an ambitious person, and I am not seeing enough results. Sometimes I speak to friends, and they tell me that FoE is not really loud, and it's true, probably because we are all volunteers. I think we have to concentrate our energy more, especially on particular areas. This is maybe the reason why I am being a pessimist in the way I see things, because I fear that we are not making a lot of change. There is some short-term effect when we have events and speak to people or when we sometimes attended informal meetings and consultation meetings, but you don't necessarily see the change. Each action or event, is probably a very small step towards a bigger goal that is not necessarily understood by the organisation. I wish to see more change and results that are more tangible. (Mary)

To be honest though, I am not very happy with the way things are going with FoE in Malta. I am afraid that the current campaign will not be successful. We need to be much more constant in our work, barging on the media incessantly. If we keep on doing sporadic activities, people will keep on not knowing much about us. (Robert)

\section{Motivators}

People volunteer for a variety of reasons, some altruistic and some based on self-interest. Omoto and Snyder (1995) suggest that having personal and self-oriented needs served by volunteering is what keeps volunteers actively involved. There are many 'benefits' that an active membership in a voluntary organisation provides, and different people gain very different things. Nevertheless, it is very difficult to pinpoint one ultimate motive why someone keeps on volunteering because human beings want many things not just one (Midgley, 1978).

The sense of competence experienced when challenges are met and the organisation is successful in its outcomes, provides an intrinsic satisfaction for volunteers (De Young, 1996). Manzo and Weinstein (1987) claim that this 'feel good' factor motivates people into taking an active role.

There are challenges that give you a real satisfaction, like when you meet with different people and speak face to face and when you discuss things with other volunteers. (...) Whatever action we do, however small or big it is, we always feel good afterwards. (...) feel proud that I am doing this practically. (Mary)

Even though Mary has a full-time job in the environment sector, she still feels that volunteering gives her more satisfaction.

Even though you still feel that you are giving a contribution towards the environment, and it is something that I enjoy doing, it is always work, and the satisfaction that you get from doing it is sometimes less than when you do something voluntarily. (Mary)

She also feels that her work with FoE gives her the opportunity to address areas that are neglected in her work. 
With FoE, I try to give more priority to areas that I do not give to at work, so that I am also doing something different. From the full-time work that I do and get paid for, sometimes I miss that I don't see society's pulse. I do a lot of bureaucratic things, which are part of the job and which are needed. (...) At work, I miss the face-to-face contact with people outside, and that is something that FoE gives me. (Mary)

Members sometimes feel that they are very much needed by the organisation, and, thus, they cannot just walk out of it. Their volunteering is powered by their commitment to help.

I do not find it in my heart to stop (...) as I know that the issues are still there and that I have to help in any way possible. (Robert)

I am also involved in so many activities and projects within the group that I have to stay to see them through. (Charlene)

The three participants also find working with others towards a common goal as motivating.

However, one of the most amazing things is working with a group of likeminded people and then effectively see changes in the things you campaign about. So it has been a great and rewarding experience. (Robert)

Working in a team always leaves a positive feeling. Sometimes we speak to people after an action, and then we all enthusiastically share the feedback from the public. I think this really builds us. (Mary)

I know that it sounds like too much work, and sometimes it is, but I am very much encouraged when I see other people in the team working, because they are all busy people, but they still dedicate all the extra time that they have towards the environment. (Charlene)

Working together in a team not only offers the opportunity to interact with other people on an acquaintance level, but it ignites even deeper relationships with others.

I feel really at home and comfortable with FoE. I enjoy meeting new people when they join in and building relationships with the people already there. The greatest friendships, I think, are built when people go abroad together, because you build something together. When you literally live with others, even if for a very short time, you can identify their values, knowing that they are sort of on the same track as you, and you feel that you are doing something together, something that you really believe in. It's challenging, and it's fun. (Mary)

The importance of friendships among members is viewed by Mary as a motivation to stay within the organisation.

I think it is a circle that won't die easily as each person, each volunteer strengthens it. (...) I also met some really nice people in the process, who will definitely remain my friends. (Mary)

Getting recognition for the work that you do makes you feel appreciated, and this feeling could be another motivation for staying on. 
Within FoE, I found people that really care about others and that appreciate the work that you do. The first time that I was thanked for giving a good idea, I was speechless. I had never been treated that way. I always feel that people are somewhat using me. Sometimes, I really feel down, because I try to give everything when I am working on something, and then others do not give back as much, they just rely on what I have done. This breaks your spirit, but, with FoE, I feel that I receive a lot in return, even if just appreciation. I also feel very welcome. I think these are the things that really keep me going with FoE. (Charlene)

Being part of the group seems to provide Mary and Charlene with an opportunity for learning. The type of learning gained is more focused on holistic personal development such as thinking skills, self-esteem and social skills. It is also more practical, and the knowledge obtained is more in line with local issues than that gained through formal education.

I am continuously learning from this experience. I am learning new skills, meeting new friends, seeing different perspectives and believing more in myself. (Charlene)

As soon as I joined, I also had the opportunity to also become a member of the board, so I had the chance to listen and learn more about certain areas and issues that FoE was lobbying for. The type of knowledge that I get from being involved with FoE is more practical than the knowledge that I gained from university. Being active in the environmental field puts you more into the actual situations. You become more in touch with the real issues that are affecting Malta and the rest of the world. (...) On the other hand, my background with FoE and my studies also help my thinking skills and (...) take a different approach to various issues at work. For example, when I have a meeting about an issue, I usually go beyond as some issues are very much linked to others. Since some experts, in view of their expertise, are focused on one or two matters, other areas may be overlooked. I ask about the other areas, I feel it is important not to overlook things. (Mary)

Mary also thinks that her work with FoE complements her studies.

Being part of FoE really helps my studies, because I constantly learn about environmental matters and work on issues which are important for Malta. At the moment, there is a big question mark about what I am going to do for my thesis. Slowly, I am finding out which are the areas that I want to tap into. The fact that, through FoE, I meet people that are sort of the gurus on particular issues helps me to get more informed about the situations in Malta and globally. (Mary)

Mary acknowledges that through her involvement with FoE she became very interested in pursuing a job within the environmental sector.

Through FoE, I started to get really interested into even working within the environmental sector full-time. It was becoming quite important for me, because I have a passion towards the environment, and I felt that I wanted to find a job that matches that passion. (...) I managed to start working in 
the environmental sector within the office of the Prime Minister. I felt really pleased when I found this work; because I knew that I was going to learn more about issues that Malta is facing and that, in some way or another, I could also give my contribution. (Mary)

On the other hand, Charlene, who is also trying to find a job in the environment and tourism sector, has been so far unsuccessful. Still she feels that her work with FoE is giving her the opportunity to learn new things and to obtain experiences which will help her in the job market.

Right now, I am working on sponsorship for FoE Malta, and I get to meet people, like businessmen, talk to them to convince them about our work and to sponsor us for events like the photographic exhibition that we are launching soon. Recently, for example, I met up with someone who sells solar panels. This is all valuable experience for me. (Charlene)

Robert really loves travelling and getting to know other young people from around the world. His narrative and energy is fuelled by his various international experiences provided by his involvement with FoE and Young FoEE. However, he admits that his constant travelling goes somewhat against his campaign against carbon dioxide emissions.

International experiences have enhanced my work with FoE in Malta. I am not very comfortable though with the fact that I have to always catch a plane to go to another country. This obviously has a really big impact on my carbon footprint. My footprint for this year is monstrous. This is a big dilemma as I really like to travel. (Robert)

\section{Conclusion}

Pro-environmental discourse has permeated everyday life, however, we definitely have not all developed a suitable pro-environmental behavioural response. Narrative inquiry studies an issue in all of its complexity, and, when seen together, these narratives highlight the limits of single-variable explanations for pro-environmental behaviour and environmental activism. These texts reveal that there is no single factor that is optimal for promoting pro-environmental behaviour and environmental activism. The participants in this study have different values and value frameworks, different levels of self-efficacy and different loci of control dispositions. Not only are these factors different in the different participants, but they also differ within the individual, at different circumstances. Pro-environmental behaviour is determined by a combination of all of these factors interacting together, and it is impossible to understand exactly how such combinations work to generate action.

The participants have also gone through different experiences throughout the course of their lives. Even though, as stated, our intention was not to generalise, the narratives seem to suggest that an individual's experiences in nature tend to develop pro-environmental attitudes and behaviour. The participants in this study all had vivid memories of experiences in nature that seem to be quite important for them. The obvious implication on ESD is that educational programmes should provide first-hand experiences in nature.

Knowledge is definitely important, and its importance comes out very clearly in the narratives, but knowledge on its own is often not enough. ESD programmes need to 
provide environmental knowledge that is coupled with direct experiences in nature that provide learners with an enduring sense of personal interconnectedness with nature that fosters environmental concern and respect (Palmer et al., 1998). Otherwise, the environment will be perceived as 'something out there', something not to be very concerned about, and ESD will be treated like any other knowledge-based venture.

These thoughts clash significantly with the fact that in Malta natural areas are on the decrease. Moreover, children seem to be spending a considerable part of their free time engaged in virtual indoor activities, becoming less and less exposed to nature and more and more environmentally desensitised. For the sake of more effective ESD, it is of utmost importance to promote the preservation and creation of local natural areas where children can experience nature directly as part of their everyday lives. The narratives have also shown that parents have quite an important role to play in fostering pro-environmental attitudes and behaviour in children through their own attitudes and behaviour. Although other role models such as peers may then take over throughout the life course of an individual, parental influence in the early childhood years seems to have a stronger influence. The narratives also highlight the importance of education in all its forms and throughout an individual's life in promoting pro-environmental attitudes and behaviour.

Through tackling the issue of climate change, this study has made us realise the local and global political dimension of environmental issues. It is also clear that fundamental change in societal behaviour requires more than just a few individuals acting on a voluntary basis - it requires societal norms and rules that compel pro-environmental behaviour (Booth, 2009). FoE, both as a transnational and as a local organisation, tries hard to bring about such political changes. Environmental activists work hard to shape the way governments, multinationals and societies in general respond to environmental issues. In this study, environmental activism is viewed as the epitome of a personal commitment towards pro-environmental behaviour, and so the motivations and challenges behind such work are viewed as important not only to learn more about volunteering in environmental organisations, but also about pro-environmental behaviour.

It is quite clear that pro-environmental attitudes and behaviour are a result of different factors and experiences. Humans are complex creatures, and their behaviour reflects their complexity. This means that behaviour cannot be easily explained, and any attempts to do so are bound to be simplistic. Thus we will resist from doing so ourselves. We picture all of the factors and experiences outlined in the narratives as possibilities, together with others, which can be present in any combination inside an individual. Each individual is unique, and their combination is also bound to be so. Before making an attempt at promoting pro-environmental behaviour, we believe that we must appreciate and understand the complexity of such behaviour and the diversity of possible factors affecting it. Trying to change behaviour by promoting just one of these factors, like knowledge, is bound to be unsuccessful. Because of its complexity, behaviour is also very difficult to change. It is easier to influence attitudes and behaviour in the childhood years than it is to change behaviour later on in life, when that behaviour has become habitual. The implication is that ESD efforts will probably yield more positive outcomes when addressed at children and young people. This does not imply, that we should focus all our ESD efforts towards a younger audience, but rather that attempts towards adult ESD should be even more intense and unrelenting rather than weak and sporadic. 


\section{References:}

Arnold, H. E., Cohen, F. G., \& Warner, A. (2009). Youth and environmental action: Perspectives of young environmental leaders on their formative influences. Journal of Environmental Education, 40(3), 27-36. DOI: 10.3200/JOEE.40.3.27-36.

Atkinson, R. (1998). The life story interview. Thousand Oaks, CA: Sage Publications Inc.

Atkinson, R. (2007). The life story interview as a bridge in narrative inquiry. In D. J. Clandinin (Ed.), Handbook of narrative inquiry - mapping a methodology (pp. 224-245). Thousand Oaks, California: Sage Publications Inc.

Ayress, L. (2008). Thematic coding and analysis. In L.M. Given (Ed.), The Sage encyclopedia of qualitative research methods. Retrieved July 31, 2012, from www.sageereference.com/research/Article_n451.html

Aytülkasapoglu, M., \& Ecevit, M. (2002). Attitudes and behavior toward the environment: The case of Lake Burdur in Turkey. Environment and Behavior, 34(3), 363377.

Balderjahn, I. (1988). Personality variables and environmental attitudes as predictors of ecologically responsible consumption patterns. Journal of Business Research, 17(1), 51-56.

Balmford, A., Clegg, L., Coulson, T., \& Taylor, J. (2002). Why conservationists should heed Poke'mon. Science, 295(5564), 2367-2367.

Bamberg, S., \& Moser, G. (2007). Twenty years after Hines, Hungerford, and Tomera: A new metaanalysis of psycho-social determinants of pro-environmental behavior. Journal of Environmental Psychology, 27(1), 14-25. DOI: 10.1016/j.jenvp. 2006.12.002.

Bandura, A. (1977). Social learning theory. Englewood Cliffs, NJ: Prentice-Hall.

Barr, S. (2007). Factors influencing environmental attitudes and behaviors: A U.K. case study of household waste management. Environment and Behavior, 39(4), 435473. DOI: $10.1177 / 0013916505283421$.

Benaquisto, L. (2008). Codes and coding. In L. M. Given (Ed.), The Sage encyclopedia of qualitative research methods. Retrieved July 31, 2012, from www.sage-ereference. com/research/Article_n48.html

Berkowitz, B. (1987). Local heroes. Lexington, Mass: Lexington Books.

Bögeholz, S. (2006). Nature experience and its importance for environmental knowledge, values and action: Recent German empirical contributions. Environmental Education Research, 12(1), 65-84.

Booth, C. (2009). A motivational turn for environmental ethics. Ethics \& The Environment, 14(1), 53-78.

Brinkmann, S. (2008). Interviewing. In L. M. Given (Ed.), The Sage encyclopedia of qualitative research methods. Retrieved July 31, 2012, from www.sage-ereference. com/research/Article_n239.html

Bruner, J. (1990). Acts of meaning. Cambridge, MA: Harvard University Press.

Chawla, L. (1998). Significant life experiences revisited: A review of research on sources of environmental sensitivity. The Journal of Environmental Education, 29(3), 11-21.

Chawla, L. (1999). Life paths into effective environmental action. The Journal of Environmental Education, 31(1), 15-26.

Chawla, L. (2006). Learning to love the natural world enough to protect it. Barn, 2, 57-78. 
Chawla, L. (2007). Childhood experiences associated with care for the natural world: A theoretical framework for empirical results. Children, Youth and Environments, 17(4), 144-170.

Clandinin, D. J., \& Connelly, M. (2000). Narrative inquiry: Experience and story in qualitative research. San Francisco: Jossey-Bass.

Clandinin, D. J., \& Rosiek, J. (2007). Mapping a landscape of narrative inquiry. In D. J. Clandinin (Ed.), Handbook of narrative inquiry - mapping a methodology (pp. 35-75). Thousand Oaks, CA: Sage Publications Inc.

Cleary, I. (2007). A call from the wild: How today's children need nature and how the future depends on it. Retrieved July 31, 2012, from http://www.kindredcommunity. com/articles/a-call-from-the-wild-how-todays-children-need-nature-and-how-thefuture-depends-on-it/p/1186

Cleveland, M., Kalamas, M., \& Laroche, M. (2005). Shades of green: Linking environmental locus of control and pro-environmental behaviors. Journal of Consumer Marketing, 22(4), 198-212.

Connelly, F. M. \& Clandinin, D. J. (1990). Stories of experience and narrative inquiry. Educational Researcher, 19(5), 2-14.

De Young, R. (1996). Some psychological aspects of reduced consumption behaviour: The role of intrinsic satisfaction and competence motivation. Environment and Behavior, 28(3), 358-409.

De Young, R. (2000). New ways to promote proenvironmental behavior: Expanding and evaluating motives for environmentally responsible behavior. Journal of Social Issues, 56(3), 509-526.

Dietz, T., Fitzgerald, A., \& Shwom, R. (2005). Environmental values. Annual Review of Environment and Resources, 30, 335-372.

Dietz, T., \& Stern, P. C (1995). Toward a theory of choice: Socially embedded preference construction. Journal of Socio-Economics, 24(2), 261-279.

Eckersley, R. (1989). Green politics and the new class: Selfishness or virtue? Political Studies, 37(2), 205-223.

Eckersley, R. (1992). Environmentalism and political theory: Toward an ecocentric approach. Albany, NY: State University of New York Press.

Elgin, D. (2010). Voluntary simplicity: Toward a way of life that is outwardly simple, inwardly rich. New York: HarperCollins Publishers.

Ellis, R., \& Thompson, F. (1997). Seeing green: Cultural biases and environmental preferences. In R. Ellis \& M. Thompson (Eds.), Culture matters: Essays in memory of Aaron Wildavsky (pp. 169-188). Boulder: Westview Press.

Emmons, K. M. (1997). Perspectives on environmental action: Reflection and revision through practical experience. The Journal of Environmental Education, 29(1), 34-44.

Finger, M. (1994). From knowledge to action? Exploring the relationships between environmental experiences, learning and behavior. Journal of Social Issues, 50(3), 141-160.

Franzosi, R. (1998). Narrative analysis - or why (and how) sociologists should be interested in narrative. Annual Review of Sociology, 24(5), 517-554.

Freeman, M. (1997). Why narrative? Hermeneutics, historical understanding, and the significance of stories. Journal of Narrative and Life History, 7(1/4), 169-176. 
Freeman, M. (2003). Identity and difference in narrative inquiry: A commentary on the articles by Erica Burman, Michelle Crossley, Ian Parker, and Shelley Sclater. Narrative Inquiry, 13(2), 331-346.

Gready, P. (2008). The public life of narratives: Ethics, politics, methods. In M. Andrews, C. Squire \& M. Tamboukou (Eds.), Doing narrative research (pp. 137-150). London: Sage Publications Ltd.

Gudmundsdottir, S. (2001). Narrative research on school practice. In V. Richardson (Ed.), Fourth handbook for research on teaching (pp. 226-240). New York: MacMillan.

Hamid, P. N., \& Cheng, S. (1995). Predicting anti-pollution behavior: The role of moral behavioral intentions, past behavior, and locus of control. Environment and Behavior, 27(5), 649-698.

Hines, J. M., Hungerford, H. R., \& Tomera, A. N. (1986-1987). Analysis and synthesis of research on responsible environmental behavior: A meta-analysis. Journal of Environmental Education, 18(2), 1-8.

Hungerford, H., \& Volk, T. (1990). Changing learner behavior through environmental education. Journal of Environmental Education, 21(3), 8-21.

Hwang, Y., Kim, S., \& Jeng, J. (2000). Examining the causal relationships among selected antecedents of responsible environmental behavior. The Journal of Environmental Education, 31(4), 19-25.

Ignatow, G. (2006). Cultural models of nature and society: Reconsidering environmental attitudes and concern. Environment and Behavior, 38(4), 441-461.

Jenkins, D., Bauer, J., Bruton, S., Austin, D., \& McGuire, T. (2006). Two faces of American environmentalism: The quest for justice in Southern Louisiana and sustainability in the Sonoran Desert. In J. Bauer (Ed.), Forging environmentalism: Justice, livelihood and contested environments (pp. 263-326). New York: ME Sharp Inc.

Jensen, R. (2006). What is a morally defensible level of consumption? In S. Best \& A. J. Nocella (Eds.), Igniting a revolution: Voices in defence of the Earth (pp. 107113). Oakland, CA: AK Press.

Josselson, R. (2006). Narrative research and the challenge of accumulating knowledge. Narrative Inquiry, 16(1), 3-10.

Kals, E., Schumacher, D., \& Montada, L. (1999). Emotional affinity toward nature as a motivational basis to protect nature. Environment and Behavior, 31(2), 178202.

Kaplan, S. (2000). Human nature and environmentally responsible behavior. Journal of Social Issues, 56(3), 491-50.

Klineberg, S. L., McKeever, M., \& Rothenbach, B. (1998). Demographic predictors of environmental concern: It does make a difference how it's measured. Social Science Quarterly, 79(4), 734-753.

Kollmuss, A., \& Agyeman, J. (2002). Mind the gap: Why do people act environmentally and what are the barriers to pro-environmental behavior? Environmental Education Research, 8(3), 239-260.

Louv, R. (2005). Last child in the woods: Saving our children from nature deficit disorder. Chapel Hill, NC: Algonquin Books.

Manzo, L. C., \& Weinstein, N. D. (1987). Behavioral commitment to environmental protection: A study of active and non-active members of the Sierra Club. Environment and Behavior, 19(6), 673-694. 
Mc Adams, D. P. (1997). The stories we live by: Personal myths and the making of the self. New York: Guilford Press.

McCarty, J. A., \& Shrum, L. J. (2001). The influence of individualism, collectivism, and locus of control on environmental beliefs and behavior. Journal of Public Policy and Marketing, 20(1), 93-104.

Midgley, M. (1978). Beast and man: The roots of human nature. New York: New American Library.

Mifsud, M. C. (2008). The actors that shape the knowledge, attitudes and behaviour of Maltese youth. In P. Pace (Ed.), Thinking and acting outside the box. Conference Proceedings of the 10th Conference on Environmental Education in Europe (pp. 17). Valletta: Malta.

Ministry of Education, Employment and the Family. (2011). Towards a quality education for all: The National Curriculum Framework 2011. Consultation document 2: Rationale and components. Valletta: Ministry of Education, Employment and the Family.

Moen, T. (2006). Reflections on the narrative research approach. International Journal of Qualitative Methodology, 5(4). Retrieved July 31, 2012, from http://www.ualberta. ca/ iiqm/backissues/5_4/pdf/moen.pdf

Newhouse, N. (1990). Implications for attitude and behavior research for environmental conservation. Journal of Environmental Education, 22(1), 26-32.

Nordlund, A. M., \& Garvil, J. (2002). Value structures behind proenvironmental behavior. Environment and Behavior, 34(6), 740-756.

Olli, E., Grendstad, G., \& Wollebaek, D. (2001). Correlates of environmental behaviors: Bringing back social context. Environment and Behavior, 33(2), 181-208.

Omoto, A. M., \& Snyder, M. (1995). Sustained helping without obligation: Motivation, longevity of service, and perceived attitude change among AIDS volunteers. Journal of Personality and Social Psychology, 68(4), 671-686.

Oskamp, S. (2000). Psychological contributions to achieving an ecologically sustainable future for humanity. Journal of Social Issues, 56(3), 373-390.

Oskamp, S. (2002). Environmentally responsible behavior: Teaching and promoting it effectively. Analyses of Social Issues and Public Policy, 2(1), 173-182.

Ozmete, E. (2007). An evaluation of locus of control as a system of life management: A case study on youth. World Applied Sciences Journal, 2(S), 691-698.

Pace, P. (1997). Environmental education in Malta: Trends and challenges. Environmental Education Research, 3(1), 69-82.

Palmer, J. (1993). Development of concern for the environment and formative experiences of educators. Journal of Environmental Education, 24(3), 26-30.

Palmer, J. A., Suggate, J., Bajd, B., Hart, P. K. P., Ho, R. K. P., Ofwono-Orecho, J. K. W. ... Van Staden, C. (1998). An overview of significant influences and formative experiences on the development of adults' environmental awareness in nine countries. Environmental Education Research, 4(4), 445-464.

Patterson, B. (2000). Build me an ark. New York: Norton.

Patterson, W. (2008). Narratives of events: Labovian narrative analysis and its limitations. In M. Andrews, C. Squire \& M. Tamboukou (Eds.), Doing narrative research (pp. 22-40). London: Sage Publications Ltd.

Pelletier, L., Dion, S., Tuson, K., \& Green-Demers, I. (1999). Why do people fail to adopt environmental protective behaviors? A taxonomy of environmental amotivation. The Journal of Applied Social Psychology, 29(12), 2481-2504. 
Pelletier, L., Tuson, K., Green-Demers, I., Noels, K., \& Beaton, A. (1998). Why are you doing things for the environment? The Motivation toward the Environment Scale (MTES). Journal of Applied Social Psychology, 28(5), 437-468.

Pergams, O. R. W., \& Zaradic, P. A. (2006). Is love of nature in the U.S. becoming love of electronic media? 16-year downtrend in national park visits explained by watching movies, playing video games, internet use, and oil prices. Journal of Environmental Management, 80(4), 387-393.

Phoenix, A. (2008). Analysing narrative contexts. In M. Andrews, C. Squire \& M. Tamboukou (Ed.), Doing narrative research (pp. 64-77). London: Sage Publications Ltd.

Plummer, K. (2001). Documents of life 2: An invitation to critical humanism. London: Sage Publications Ltd.

Poortinga, W., Steg, L., \& Vlek, C. (2002). Environmental risk concern and preferences for energy-saving measures. Environment and Behavior, 34(4), 455-478.

Riessman, C. K. (1993). Narrative analysis. Qualitative research methods series, No. 30. Newbury Park, CA: Sage Publications.

Schultz, P. (2000). Empathizing with nature: The effects of perspective taking on concern for environmental issues. Journal of Social Issues, 56(3), 391-406.

Schultz, P., \& Oskamp, S. (1996). Efforts as a moderator of the attitude-behavior relationship: General environmental concern and recycling. Social Psychology Quarterly, 59(4), 375-383.

Schultz, P., Oskamp, S., \& Mainieri, T. (1995). Who recycles and when - a review of personal and situational factors. Journal of Environmental Psychology, 15(2), 105121.

Shaw, S. (2000) Childhood and nature. Retrieved July 31, 2012, from http://www. ecopsychology.org/journal/gatherings/childhoo.htm

Shrum, L. J., Lowrey, T. M., \& McCarty, J. A. (1994). Recycling as a marketing problem: A framework for strategy development. Psychology and Marketing, 11(4), 393416.

Smith-Sebasto, N., \& Fortner, R.W. (1994). The environmental action internal control index. Journal of Environmental Education, 25(4), 23-29.

Sobel, D. (1996). Beyond ecophobia: Reclaiming the heart of nature education. Great Barrington, MA: The Orion Society.

Sobel, D. (2008). Children and nature: Design principles for educators. Portland ME: Stenhouse Publishers.

Squire, C. (2008). Experience-centred and culturally-oriented approaches to narrative. In M. Andrews, C. Squire \& M. Tamboukou (Eds.), Doing narrative research (pp. 41-63). London: Sage Publications Ltd.

Stern, P. C. (2000a). Toward a coherent theory of environmentally significant behavior. Journal of Social Issues, 56(3), 407-424.

Stern, P. C. (2000b). Psychology, sustainability, and the science of human-environment interactions. American Psychologist, 55(5), 523-530.

Stern, P. C., \& Dietz, T. (1994). The value basis of environmental concern. Journal of Social Issues, 50(1), 65-84.

Stern, P., Dietz, T., Abel, T., Guagnano, G., \& Kalof, L. (1999). A value-belief-norm theory of support for social movements: The case of environmentalism. Human Ecology Review, 6(2), 81-97. 
Stern, P., Dietz, T., \& Kalof, L. (1993). Value orientations, gender and environmental concern. Environment and Behavior, 25(3), 322-348.

Tanner, T. (1980). Significant life experiences: A new research area for environmental education. The Journal of Environmental Education, 11(4), 20-24.

Tanner, T. (1998). Choosing the right subjects in significant life experiences research. Environmental Education Research, 4(4), 399-417.

Thompson, S. C. G., \& Barton, M. A. (1994). Ecocentric and anthropocentric attitudes toward the environment. Journal of Environmental Psychology, 14(2), 149-157.

Tognacci, L. N., Weigal, R. H., Wideen, M. F., \& Vernon, D. T. (1972). Environmental quality: How universal is public concern? Environment and Behavior, 4(1), $73-$ 86.

Trittin, J. (2009). Ecological materialism: How nature becomes political. Eurozine. Retrieved July 31, 2012, from http://www.eurozine.com/pdf/2009-10-30-trittinen.pdf

UNCED (United Nations Conference on Environment and Development). (1992). Agenda 21, the United Nations programme of actions from Rio. New York: UN Department of Public Information.

UNESCO (United Nations Educational, Scientific and Cultural Organisation). (2005). United Nations Decade of Education for Sustainable Development (2005-2014): Draft International Implementation Scheme. Paris: UNESCO.

UNESCO (United Nations Educational, Scientific and Cultural Organisation). (2007). Highlights on DESD progress to date: April 2007. Retrieved July 31, 2012, from http://www.desd.org/Highlights \%20on \%20ESD \%20progress-\%20April\% 202007.pdf

UN (United Nations). (2004). World youth report 2003: The global situation of young people. New York: United Nations.

UN (United Nations). (2007). World youth report 2007: Young people's transition to adulthood: Progress and challenges. New York: United Nations.

Wells, N. M., \& Lekies, K. S. (2006). Nature and the life course: Pathways from childhood nature experiences to adult environmentalism. Children and Youth Environment, 16(1), 1-25.

White, R., \& Stoecklin, V. L. (2008) Nurturing children's biophilia: Developmentally appropriate environmental education for young children. Retrieved July 31, 2012, from http://www.whitehutchinson.com/children/articles/downloads/nurturing.pdf

\section{Correspondence:}

Karen Buttigieg, G.F. Abela Junior College, Msida, Malta. Email: karen.buttigieg@um.edu.mt 